\title{
Lest We Forget: A Historical Analysis of Police Line of Duty Deaths in Indianapolis
}

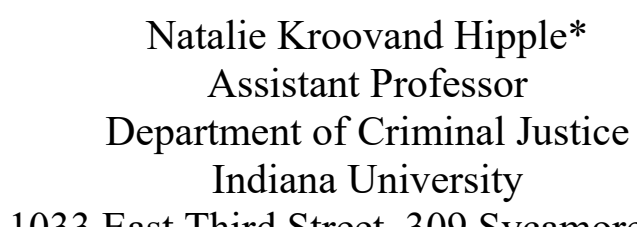

1033 East Third Street, 309 Sycamore Hall

Bloomington, IN 47405

nkroovan@indiana.edu

812.856.2759

Jeff Gruenewald

School of Public and Environmental Affairs

Indiana University-Purdue University, Indianapolis

John Gonsler

D. Jackson Sargent

Department of Criminal Justice

Indiana University

May 2017

*Corresponding Author

Acknowledgments: The authors would like to thank Jean Ritsema and Patrick Pearsey for their help verifying facts as well as the countless individuals within the IMPD family who have made never forgetting a fallen officer their passion. 


\begin{abstract}
Previous studies on police line of duty deaths are limited by their heavy reliance on traditional data. While the FBI's Law Enforcement Officers Killed and Assaulted (LEOKA) data have undoubtedly advanced what we know about violence against police, placing line of duty deaths in their social and historical context poses challenges. Further, only a select number of variables are available for event-level analyses from traditional data sources. In this study, we utilise data culled from several open-source materials to present a comprehensive analysis of police line of duty deaths in Indianapolis, Indiana from 1880 to 2014. Descriptive findings for several incident, victim, and offender-level variables are presented, while placing fatal attacks on police within their sociohistorical and situational contexts. Two themes emerging from open-source data are also used to make sense of our descriptive findings. The first theme captures shifting circumstances from public to private line of duty deaths, while the second theme suggests how advancing technologies have been used to benefit police work while also introducing new risks to officer safety.
\end{abstract}

Keywords: homicide, police, line of duty deaths, historical analysis, open-source data 


\section{Introduction}

Law enforcement can be a dangerous profession in the United States, as officers face risks of being both intentionally and accidentally killed while on the job. While officer fatalities appear to be declining over time and homicide was the cause of death in less than 10 percent of all workrelated deaths in 2014, law enforcement officers continue to rank among the most likely to become victims while on the job (Bureau of Labor Statistics, 2015). Empirical studies spanning several decades have examined the phenomenon of police killed in the line of duty, advancing what is known about where police are most likely to be killed and the circumstances under which police die (e.g., Bristow, 1963; Cardarelli, 1968; Lester, 1978b, 1984). With few exceptions, which are generally limited in time and by jurisdictional boundaries, previous research has relied on official data from police agencies and Law Enforcement Officers Killed and Assaulted (LEOKA) reports published as part of the Federal Bureau of Investigation's (FBI) Uniform Crime Reporting (UCR) Program.

Despite previous advances in research, the types of information that can be gleaned from police data remain limited, thus impeding what can be learned about fatal attacks against police officers. We contribute to the extant literature in the current study by considering in more depth the situational and sociohistorical contexts of police killed in the line of duty incidents in Indianapolis, Indiana from 1880 to 2014. Narrative accounts of police killed in the line of duty incidents are reconstructed using several different sources of publicly available data. Our approach

allows us to better conceptualise homicides as multi-dimensional events involving background factors, violent transactions, and incident aftermaths characteristics that contribute to deadly outcomes for police. 
While our study serves as a single snapshot of Indianapolis history, we contextulise our findings through the narrative themes of social and technological change that emerged from close readings of reconstructed line of duty death narratives. In particular, we explore how circumstances of risk laden situations faced by police were shaped by changes in the local economy, culture, and the professionalization of police. In addition, we also investigate how technological innovations have simultaneously made police work more efficient and more dangerous, specifically focusing on changes in communication systems, transportation, and weaponry over the $20^{\text {th }}$ century.

In this study, we analyze data about line of duty deaths in Indianapolis, Indiana from the formation of the Indianapolis Police Department (now Indianapolis Metropolitan Police Department [IMPD]) to 2014. We rely on open-source data that come from local journalistic accounts, unpublished manuscripts, historical books and book chapters, and websites devoted to fallen officers. In this way, we follow a growing trend in research on homicide and other criminological topics that rely on alternative open-source data and methodologies (Parkin \& Gruenewald, 2015), which have increasingly shown to be reliable (Chermak, Freilich, Parkin, \& Lynch, 2012). The research question guiding this study is: What is the nature of police killed in the line of duty incidents in Indianapolis, Indiana?

\section{Research Setting: Indianapolis and the Indianapolis Police Department}

We begin by providing a brief history of Indianapolis and the evolution of the Indianapolis Police Department from the late 1800 s to the early 2000 s. Located centrally in the state, Indianapolis has been Indiana's largest city since the 1860 s, serving as the seat of Marion County (Tenuth, 2004). The landlocked Midwestern city encompasses nearly 400 square miles and became known for its fertile plains. Originally established in 1852, the Indianapolis Police Department (IPD) grew in size as the city expanded to become the leading hub for agricultural commerce 
(Indianapolis Police Historical \& Educational Foundation, 2008). Uniformed officers began conducting day patrols with the department consisting of a chief, two lieutenants, more than 20 patrolmen, two detectives, and 16 special officers. Indianapolis' population grew exponentially during the latter part of the $19^{\text {th }}$ century, reaching nearly 170,000 by 1900 , with the size of the police force growing to 160 sworn officers.

The turn-of-the- $20^{\text {th }}$-century brought several major socioeconomic changes, similar to other large northern cities that were transitioning from an agrarian-based economy to a modern, industrialised system of labor. Like cities and towns across the country, urban economies were hit hard by the Great Depression. With Indianapolis' population nearing 300,000 in 1930, residents found themselves competing for jobs and scarce resources (Tenuth, 2004). Similar to larger cities like Chicago (Adler, 1999; Gruenewald \& Pridemore, 2009), Indianapolis had become increasingly segregated, relegating poor immigrants and racial minorities to marginalised sections of the city. Following the emancipation of black slaves, Indianapolis joined other northern cities in attempting to halt freed slaves from migrating to their city. The fierce competition for jobs as well as other issues of racism opened the door for the Ku Klux Klan (KKK) and white supremacy, dominating mainstream Indianapolis politics during the 1920s and 1930s (Tenuth, 2004). Also around this time, urban policing became less tied to the local political scene and a more respectable profession (Monkkonen, 1981). IPD and other large agencies began to centralise operations and develop rational administrative procedures. Educational and training requirements were increasingly placed on officers throughout the $20^{\text {th }}$ century as they began to view themselves as professional enforcers of the law (Walker, 1977).

Sparked by a resurgence in manufacturing during World War II, economic growth and prosperity reignited in Indianapolis throughout the middle part of the $20^{\text {th }}$ century. IPD continued 
to professionalise and add women and minorities to its ranks, initially to replace men who were away at war and later in response to the Civil Rights and feminist movements. By the end of the 1960s, female and black officers were working beats across all parts of the city. In 1968, IPD became the first department in the country to assign female officers to patrol cars (City of Indianapolis, 2016; Indianapolis Police Historical \& Educational Foundation, 2008).

Unfortunately, this upward momentum was eventually curbed by a once again shifting economy during the late 1970s and early 1980s. Decent paying manufacturing jobs began to disappear or move overseas to be replaced by lower wage service employment opportunities (Anderson, 1990; Massey \& Denton, 1993; W. J. Wilson, 1996). The deindustrialization of Indianapolis had a lasting effect on many of the city's downtown neighborhoods. While high-end retail outlets, professional sports, and other specialised markets flourished, generations of bluecollar workers found themselves unemployed and living in conditions of extreme poverty. Violent crime increased in many of the city neighborhoods hardest hit by physical and social decay (Shihadeh \& Ousey, 1998). Though the city has always been on the cusp of implementing innovative strategies for reducing crime, Indianapolis recently ranked ninth for total violent crimes in the country and $18^{\text {th }}$ for its homicide rate among cities with a population greater than 250,000 (1254.7/100,000 residents) (Federal Bureau of Investigation, 2015).

In 2007, the police department was reorganised when the Indianapolis Police Department (IPD) and the patrol division of the Marion County Sheriff's Department (MCSD) ${ }^{1}$ merged to form the Indianapolis Metropolitan Police Department (IMPD). The new department maintained the rank and file structure of IPD and now included the geographic patrol jurisdiction of the MCSD, creating a county-wide jurisdiction. Today, IMPD officers are responsible for protecting and

\footnotetext{
${ }^{1}$ Now the Marion County Sherriff's Office
} 
serving approximately 850,000 residents (United States Census Bureau, 2015). IMPD is currently the $29^{\text {th }}$ largest police department in the United States based on the number of sworn personnel. According to the 2013 Law Enforcement Management and Administrative Statistics (LEMAS) Survey, IMPD employed 1,589 sworn officers, or 19 officers per 10,000 population (Reaves, 2015). Approximately 80 percent of all sworn employees hold the rank of patrol officer, while 73 percent of all sworn officers are white males and 13 percent are female (R. Riddle \& B. Roach, personal communication, May 23, 2016). Between 2010 and 2014, three IMPD officers were killed in the line of duty. Of the 15 largest cities in the U.S. (United States Census Bureau, 2015), there were only three police departments that lost more officers during this time period: New York Police Department, Chicago Police Department, and Phoenix Police Department (4, 5, 4 respectively). Importantly, all three of these departments are considerably larger than IMPD and serve larger populations.

\section{Narrative Themes}

Prominent themes or storylines emerged from a process of reading and re-reading Indianapolis police officer line of duty death case narratives to aid in contextualising these events. The first narrative theme addresses how situated circumstances of Indianapolis line of duty deaths to a large extent evolved from the drunken public brawls and gambling raids during the turn-ofthe- $20^{\text {th }}$-century to increasingly one-on-one encounters between individual citizens and police

officers. The second theme more directly addresses how advancing police technologies and equipment, while making police work more efficient, introduced new risks to officer safety.

\section{Victim (Officer) Variables}

Several victim-level variables were also captured for each of the fallen Indianapolis officers. First, researchers coded for victim demographics, including officer race (1=White, 
$0=$ Non-White $)$ and gender $(1=$ Male, $0=$ Female). Second, researchers coded for how police officers were killed, or method of death, as 1=Gunshot, 2=Electrocution, 3=Motorcycle Accident, 4=Automobile Accident, and 5=Other. Third, the time on the police force before an officer was killed (number of years) and the rank of the officer (1=Patrol, 2=Detective, $3=$ Sergeant, 4=Lieutenant, and 5=Other) were captured. Fourth, two binary-coded variables were included in this study to examine the marital status ( $1=$ Married, $0=$ Unmarried) and if officers had children at the time of their death ( $1=$ Children, $0=$ No Children).

Evolving Circumstances. Around the turn of the $20^{\text {th }}$ century, police line of duty deaths often occurred in public settings, specifically outdoor locations where people tended to congregate. Like other northern cities during the early industrialization era, Indianapolis was experiencing a manufacturing boom (Tenuth, 2004), which brought with it a rapid influence of working class males migrating north from southern states in search of low-skill employment (Park, Burgess, \& McKenzie, 1984). Flocks of young males arrived in the city detached from their families where they found themselves among strangers originating from a variety of social and cultural backgrounds. As these men sought companionship at local saloons, common to the downtown area were drunken brawls and quarrels over gambling and other forms of deviant pastimes (Adler, 1999; Chudacoff, 1999). These fights sometimes spiraled out of control and posed significant dangers to police. During this period, many of the laws and local ordinances designed to prevent public disorder did not exist or remained unenforced. Officers also had much less training in law enforcement and order maintenance practices.

Eventually, Indianapolis began to evolve as the downtown's demographic makeup shifted over the $20^{\text {th }}$ century. Working-class males began to relocate their families to Indianapolis to start new lives. Many urban centers like Indianapolis witnessed middle-class white and wealthy black 
downtown residents begin to relocate to the developing suburban neighborhoods outside of the city center (Shaw \& McKay, 1942). As one might expect, the situated threats to police officers also shifted over time with more officers encountering violence in private residences, such as in the context of domestic violence and the homes of disturbed individuals. We consider these social and demographic changes to contextualise line of duty death events in Indianapolis.

Advancing Technology and Equipment. Another theme that emerged from our reading of case materials concerns how advances in technology and equipment adopted by the police agency simultaneously made work more efficient and riskier. Our focus is on three specific forms of police equipment that experienced significant advances over the last century - transportation (e.g., cars and motorcycles), communication systems, and weaponry.

Prior to the turn of the $20^{\text {th }}$ century, officers primarily operated on foot. Bicycles were also used when officers needed to get somewhere more quickly with horse patrols increasing in Indianapolis around 1900 (City of Indianapolis, 2016). The use of motorcycles as a means of transportation was increasing across the United States as well and. by the end of the first decade of 1900, the Indianapolis police had begun to rely on them as an inexpensive mode of transportation. During this time, more people and automobiles began to fill the narrow streets of downtown Indianapolis and congestion and crime became more problematic. By 1920, one of the most significant developments in police equipment arrived when the police department purchased automobiles. These new vehicles allowed police to patrol and respond to calls for service more efficiently across the flourishing city, while providing officers more protection from the elements and those who wished them harm. Importantly, though, advances in police use of transportation also posed unique risks to officer safety, as several Indianapolis officers have been killed while operating motorcycles and automobiles. 
Police communication systems have also seen significant advances since the turn-of-the$20^{\text {th }}$-century as radio transmission and telephone technologies have improved (Chapman, 1998; Monkkonen, 1992; Rubinstein, 1973). Again, though, as police communication technology progressed, new risks to officer safety were also introduced. First used in Washington D.C., call boxes were installed around Indianapolis in the 1890s so officers walking and riding the beat could provide one-way communication back to police headquarters. This technology was a major innovation for officers who could call for assistance and update headquarters on developing situations. Unfortunately, metal call boxes connected by electrical wires also posed serious risks to officers when they periodically became electrified, such as during lightning storms, electrocuting and killing some officers. Police radios introduced in 1929 (City of Indianapolis, 2016) alleviated some of the this risk by providing an alternative means of communication, with two-way handheld radios eventually revolutionizing communication for Indianapolis officers in 1938.

Finally, the increasing availability and lethality of firearms mass produced after the Civil War (Beeghley, 2004) greatly impacted the dangers officers faced on the job. In the early $20^{\text {th }}$ century, gun ownership became feasible for most Americans as they became less expensive and more culturally acceptable (Weaver, 2002). Urban police departments were required to respond to the arming of America by arming themselves. While claiming firearms pose risks to officer safety may seem obvious, two additional points are worth note. First, officers were poorly trained prior to the police professionalization movement that did not begin until well into the 1900s (Roth, 2012). This lack of training most likely extended to the use of firearms in police work. In contrast, officers of today undergo significant training for use of their service weapons. Second, gun ownership precipitously shifted from long guns (i.e., rifles, shotguns) to handguns over the course 
of the $20^{\text {th }}$ century (Cook, 1983). While handguns became an increasingly useful tool for officers, they also became much easier weapons for criminals to conceal and use against police. Combined with the risks faced by officers with increasingly common traffic stops, calls to private residences, and other circumstances where weapons became more difficult to detect over the $20^{\text {th }}$ century, innovations in firearm technologies provided both security and severe risks to officers in Indianapolis and urban settings across the country. Of course the risks of being shot in the line of duty have only increased in more recent times for officers as the number of guns have increased dramatically in Indianapolis and other cities around the country.

\section{Prior Research on Line of Duty Deaths}

A number of empirical studies have examined police killed in the line of duty with Bristow (1963) being one of the earliest known scholars to focus on this topic. Details on how data were collected for this study are few, but it can be ascertained that information was initially collected on California cases through personal interviews and nationally through written correspondence. Examining 110 cases, Bristow (1963) focused on several tactical issues with the aim of informing police training, finding that police officers were often killed while working on the streets or highways, and usually with firearms. Another early study by Cardarelli (1968) used data from the Uniform Crime Reporting (UCR) program to examine police officers killed in the line of duty during the early 1960s. One of the first studies to correlate police homicide rates with crime rates more generally, this study found police murder rates trended in similar ways as homicides across different parts of the country (see also Lester, 1978b, 1984).

At the incident level, ${ }^{2}$ situational factors resulting in police murders have been of considerable interest to scholars. Research has shown some of the most common circumstances

\footnotetext{
${ }^{2}$ While we recognise several past studies have examined macro-level variations in homicides targeting police (e.g., Batton \& Wilson, 2006; Chamlin, 1989; Jacobs \& Carmichael, 2002; Kaminski, 2004, 2008; Kaminski \& Marvel,
} 
resulting in police homicides have involved arrest situations (Brown \& Langan, 2001; Chapman, 1976, 1986; Geller \& Scott, 1992; Konstantin, 1984; Little, 1984; Pinizzotto \& Davis, 1992), such as police initiated activities related to robbery calls (Cardarelli, 1968; Garner \& Clemmer, 1986; Margarita, 1980a). Other common situations leading to officer deaths included responses to disturbances, traffic stops, and vehicle pursuits. As for weapons used in police homicides, research has shown that the vast majority of officers killed (over 90\%) fell victim to fatal shootings (Bristow, 1963; Brown \& Langan, 2001; Chapman, 1976, 1986; Edwards, 1995; Geller \& Scott, 1992; Little, 1984; Pinizzotto \& Davis, 1992; Zimring \& Arsiniega, 2015). Several studies have also indicated police homicides are most likely to occur in the South (Bristow, 1963; Cardarelli, 1968; Chapman, 1986; Edwards, 1995; Fridell \& Pate, 1997; Geller \& Scott, 1992; Robert J. Kaminski, 2004; Robert J Kaminski, 2008; Robert J. Kaminski, Jefferis, \& Chanhatasilpa, 2000; Lester, 1978a; Little, 1984; Pinizzotto \& Davis, 1992; Pinizzotto, Davis, \& Miller III, 1997, 2006), while the Northeast has consistently accounted for the smallest percentage of such incidents.

As for victims, research has shown that most police officers were relatively new to the profession with less than ten years of service at the time of their deaths, usually before they turned 40 years old ${ }^{3}$ (see also, Brown \& Langan, 2001; Geller \& Scott, 1992; Margarita, 1980b). More precisely, studies have found the average age of officers killed in the line of duty to be between 34 and 36 (Edwards, 1995; Pinizzotto \& Davis, 1992; Tucker-Gail, Selman, Kobolt, \& Hill, 2010). In addition to being young, studies have shown most officers killed in the U.S. have been white (Brown \& Langan, 2001; Cardarelli, 1968; Chapman, 1976, 1986, 1998; King \& Sanders, 1997;

2002; Kaminski \& Stucky, 2009; Peterson \& Bailey, 1988), the primary focus of this review will be on incidentlevel patterns.

${ }^{3}$ In contrast, Chapman $(1976,1986)$ found the average age of officers killed in Oklahoma was approximately 41. 
Konstantin, 1984; Little, 1984; Pinizzotto \& Davis, 1992; Wilbanks, 1994) and male (see also, Chapman, 1998; Edwards, 1995; Geller \& Scott, 1992).

Focusing on offender characteristics, prior research has estimated offender ages to range from 18 to around 30 years of age (Geller \& Scott, 1992; Little, 1984), while one study offered a more precise estimate of 26 years of age (Pinizzotto \& Davis, 1992). Most offenders (54 to 60\%) who kill officers in the line of duty have been found to be white (Brown \& Langan, 2001; Konstantin, 1984; Little, 1984; Pinizzotto \& Davis, 1992), though this has been shown to vary considerably in some cities (Wilbanks, 1984). Similar to victims of police homicides, research has shown offenders are overwhelmingly male (ranging from 94 to 100\%) (Brown \& Langan, 2001; Chapman, 1976, 1986; Little, 1984; Pinizzotto \& Davis, 1992; Wilbanks, 1994).

Especially relevant to the current research, past studies of police homicides have focused on localised areas, often in high-crime urban centers like Chicago and Baltimore (Geller \& Karales, 1982; Uchida \& Brooks, 1988). Bridges and Hegner (1976), for example, looked at killings of police officers in a single state, California, from 1960 to 1974. They reported police homicide rates varied from year to year but were consistently higher than the homicide rate for the general population. Other researchers have studied the killings of police in specific cities over long periods of time. In one such study, Margarita (1980a) examined the situational motives of the suspects who killed New York City officers in the line of duty. The sample included 245 criminal homicides of New York Police Department officers from 1844 to $1978 .{ }^{4}$ The author devised a classification scheme including five primary motives for killing officers. She concluded police homicides were not usually committed during domestic disputes (see also Kercher, Swedler, Pollack, \& Webster, 2013), by the mentally ill, or by political terrorists, but rather during armed robberies or weapons

\footnotetext{
${ }^{4}$ The data source is somewhat unclear for this study as it is described as "a unique data maintenance system and enthusiastic departmental cooperation" (Margarita, 1980a, p.64).
} 
offense incidents. Wilbanks (1994) also honed his analysis of police homicides to a more confined location - Dade County, Florida. The sample included 103 law enforcement officers from 21 different agencies occurring from 1895 to 1993, though his analysis was not limited to homicides. Data were culled from newspaper articles as well as official records from the police, the court, the medical examiner, and the prison. He reported characteristics of victims, offenders, and homicide events along with information on the sentences of "cop killers."

\section{Limitations of Prior Research}

While analyses of official data sources like LEOKA have greatly advanced our understanding of police killed in the line of duty incidents, prior studies are limited by their heavy reliance on such data. One major issue with only using official data to study this topic is that official data remain unavailable for police homicides occurring around the turn of the $20^{\text {th }}$ century or earlier, thus making historical analyses impossible. Another issue is that few variables are available in official data that can be used to capture the multi-dimensionality of police killed in the line of duty events. LEOKA does provide narratives for each line of duty death - those from 1996 forward are easily accessible on the LEOKA website. However, narratives are only included for those incidents fully concluded or disposed of through the court system; ongoing investigations or open case are not included. Because LEOKA data are not collected for research purposes, ${ }^{5}$ there is inconsistent reporting and the narratives vary widely in incident detail (Kercher et al., 2013). For example, a quick survey of the available narratives from 1996 to 2014 reveals a wide range of word counts (and thus details) across the five narratives - 159 to 775 words. Additional details about the situations and participants of police homicides are needed to develop a more

\footnotetext{
5 "The objective of this program is to assist law enforcement managers, trainers, and personnel in the identification of training issues for the purpose of preventing the deaths and/or serious injury of law enforcement personnel" https:/ucr.fbi.gov/ucr-program-data-collections\#Law retrieved 05.20.2017.
} 
contextualised understanding of the situations culminating in fatal attacks for police officers. Finally, there have been very few studies to date examining police homicides in a single metropolitan center over long durations of time, and no study to our knowledge has encompassed three different centuries.

\section{The Current Study}

We seek to contribute to the extant research on police killed in the line of duty in three specific ways. Data are culled from several open-sources, including journalistic accounts, historical publications, and agency records. In doing so, we avoid some of the limitations associated with official crime data discussed above. Also, we utilise a criminal event perspective (Sacco \& Kennedy, 2002) to conceptualise incidents of police killed in the line duty as multifaceted homicide events, which consist of pre-incident, transaction, and aftermath stages. As in past research, we describe police homicide situations (e.g., motivational circumstances) and participants, but we also extend prior research by exploring additional aspects of these events, such behaviors that serve to trigger and escalate deadly situations. We also contribute to the literature by focusing on a single Midwestern city for a period of time spanning three centuries as well and the entire history onepolice department.

\section{Data and Method}

The unit of analysis for the project was the officer killed in the line of duty. We used the LEOKA definition for officers killed both feloniously and accidentally in the line of duty. Officers included in this study met all of the following criteria at the time of the incident:

- Wore/carried a badge (ordinarily);

- Carried a firearm (ordinarily);

- Were duly sworn and had full arrest powers;

- Were a member of a public governmental law enforcement agency and were paid from government funds set aside specifically for payment to sworn law enforcement;

- Were acting in an official capacity, whether on or off duty, at the time of the incident; and 
- If killed, the death was directly related to the injury(ies) received during the incident. (Federal Bureau of Investigation, 2016).

The master data set used for this project first began as a list maintained by the police department (prior to the merge); however, when such record keeping actually commenced is unclear. Departmental personnel then began the process of trying to write descriptive narratives for each line of duty death. They consulted local newspaper archives as well as a line of duty death list maintained by the newspaper. During this process, names were removed from the list as it became apparent the death was not a line of duty death. Newspaper archives were the main source used for confirmation. At the same time, if a name was discovered that was not on the list, usually through related research, departmental personnel investigated the new name/incident until they were able to make a determination about inclusion or exclusion. Additionally, an early (circa 1910) pension list was discovered and used as another way to search for officers left off the list. Only two officers have been added to the list with two more pending further research. Thus, further research most often resulted in the removal of a name from the master list.

Currently, IMPD maintains a comprehensive file on every Indianapolis officer killed in the line of duty, serving as the basis for the agency's In Memoriam webpage, originally created by a civilian employee during the 1990 s. $^{6}$ Each file contains a summary of the police death authored by an agency employee and other miscellaneous journalistic ${ }^{7}$ and historical documents. In addition, researchers supplemented the information provided in the IMPD files by conducting systematic searches of The Indianapolis Star, which has been the city's largest newspaper for more than a century. For each police death, the Indianapolis Star Archive (1862-2016) was searched based on

\footnotetext{
${ }^{6}$ For more information, go to http://www.indy.gov/eGov/City/DPS/IMPD/About/Memoriam/Pages/home.aspx.

${ }^{7}$ For instance, IMPD files contained articles from Indianapolis' African American newspaper, The Recorder. In a few cases, newspapers accounts of Indianapolis police homicide published in newspapers outside of the city are also included in the IMPD files analyzed for this study.
} 
relevant case-specific keywords (e.g., year of incident, offender and victim names, etc.). ${ }^{8}$ All articles mentioning a particular police officer killed in the line of duty were collected. Finally, information from other miscellaneous sources, such as unpublished manuscripts (Ritsema \& Spears, 2015), historical books, book chapters, and websites devoted to fallen officers were also used to collect information on Indianapolis police deaths. All documents related to each incident were digitised so they could be more easily analyzed by the researchers.

In total, researchers collected articles from 14 different print media sources, while nearly 95\% of all articles came from The Indianapolis Star. The number of articles per officer death ranged from one to 171 . On average, each death produced almost 24 unique newspaper articles. Based on our review of these materials, we believe we currently have the most accurate list of all Indianapolis police officer deaths and the most inclusive set of information currently available on each case.

\section{Incident Variables}

The first incident-level variable captured was type of incident, which was coded as 1=Felonious, $2=$ Traffic, and 3=Accidental. Second, researchers also coded for the situational circumstances of police deaths. This variable was coded according to LEOKA definitions as 1=Arrest Situation, 2=Ambush Situations, 3=Traffic-Related Situations, 4=Disturbance Calls, 5=Investigating Suspicious Persons/Circumstances, 6=Tactical Situations, 7=Handling/Transporting Prisoners, 8=Other Investigative Activities, 9=Handling Persons with Mental Illness, and 10=Other Circumstances. Third, researchers coded for temporal attributes of police deaths, including the date and time of day the incident occurred. Fourth, the specific location of where the death occurred was captured (1=Business, $2=$ Residence, $3=$ Public Street or Alley,

\footnotetext{
${ }^{8}$ The Archive also contains articles from preceding newspapers (e.g., Indianapolis Sentinel) that were eventually purchased by The Indianapolis Star.
} 
4=Vehicle, and 5=Other). Fifth, the type of weapon used in the killing of an officer was also coded, measured as $1=$ Handgun, $2=$ Long Gun, and $3=$ Other. Sixth, the number of offenders involved in the police death was also measured as a continuous variable.

Researchers also measured a series of situational variables to capture the ways in which police homicides were initiated, escalated, and concluded. Thus, the seventh incident variable examined was initiation of violence, measured as $1=$ Shooting at Officers, $2=$ Ambushing Officers, 3=Engaging in a Physical Struggle with Officers, and 4=Reacting to Officers' Use of Non-Lethal Force. The eighth variable, ways situated transactions between offender and police escalated into violence, was measured as $1=$ No Escalating Factors, $2=$ Police Shows of Force, $3=$ Introduction of Third Parties, and 4=Struggle Over Weapons. Finally, how police homicide events concluded was measured with the following five categories, including $1=$ Near Immediate Surrender or Capture of Offender, 2=Offender Killed by Police 3=Offender Captured ( 1 or More Days) After Incident, 4=Offender Never Being Captured, and 5=Offender Committing Suicide.

\section{Offender Variables}

Researchers coded data for offenders determined to be responsible for felonious killings of police officers. First, offender demographics, including race ( $1=$ White, $0=$ Non-White) and gender $(1=$ Male, $0=$ Female $)$ were captured. Second, researchers coded whether offenders died at the scene of the crime $(1=$ Yes, $0=\mathrm{No})$ and if not, if the offender received the death penalty for their crime $(1=$ Yes, $0=$ No $)$.

Due to multiple coders, Cohen's Kappa was used to check for interrater reliability. Of the 220 variables compared, coders were in agreement $97 \%$ of the time. The interrater reliability was high (Cohen's Kappa=.962), ${ }^{9}$ indicating almost perfect agreement (Landis \& Koch, 1977).

$9 \mathrm{p}<.00195 \% \mathrm{CI}=(.9904, .9326)$ 


\section{Results}

A total of 68 Indianapolis police officers (i.e., IPD, MCSD, and IMPD) ${ }^{10}$ were identified and included in this study as killed in the line of duty since the department was formed in 1858 (see Appendix A for list of officers). ${ }^{11}$ For each individual death, a series of incident, victim, and offender variables were coded. Of all line of duty deaths, we found 46 (67.6\%) were felonious, or incidents involving an officer who was killed because of or while performing his or her official duties and as a direct result of a criminal act by a subject (Federal Bureau of Investigation, 2013). While the majority of the analyses in this study focus on felonious deaths, we believe it remains important to understand the variety of occupational hazards faced by police officers. Therefore, the remaining 22 incidents $(32.4 \%)$ were deemed not to be felonious deaths and therefore accidental. Accidental deaths could include anything from the aforementioned electrocution to an officer being hit by a car while directing traffic.

\section{Temporal and Geospatial Context}

The 1920s and the 1970s were particularly deadly decades for the police department with a total of 19 fatal incidents $(27.9 \%)$ occurring in these decades (see Table 1). During the Prohibition Era (1920-1933), bootlegging became very profitable and was ingrained in organised crime, posing serious risks to law enforcement. Such dangers were realised in 1928 when a college student found Officer Schoen shot in the back and lying in the street. The shooter was a suspected bootlegger who could never be located and brought to justice. Much had changed in Indianapolis by the 1970 s and for the police as well. Similarly across the nation, felonious deaths of police officers peaked in the 1970s and then started a downward trend (Quinet, Bordua, \& Lassiter, 1997;

\footnotetext{
${ }^{10}$ Because two officers were killed in two different incidents, a total of 66 line of duty incidents are considered in this study.

${ }^{11}$ Two officers were killed in World War II and one during the Vietnam War. These three officers have been removed from the analyses as their deaths were not related to their duties as police officers.
} 
S. Wilson \& Batton, 2004). Introducing advances in technology to policing, new equipment (e.g., ballistic vests) and specialised trainings were increasingly supported by federal funding available to police departments across the country (Chapman, 1998). Officers wearing ballistic vests who were shot in the torso became three times more likely to survive compared to those who were not wearing a ballistic vest (LaTourrette, 2010).

\section{[INSERT TABLE 1 ABOUT HERE]}

The average number of days between Indianapolis police officers being killed while on duty is approximately 660 days, or just less than two years. ${ }^{12} \mathrm{~A}$ study on Oklahoma police officers conducted by Chapman (1998) reported the average time between 'officer-murder' incidents as 282 days however this was only for a 45 -year time period. As for precisely when Indianapolis police deaths were most likely to occur, we found more than 13 percent of incidents occurred in January and July (see Table 3), on Tuesdays (25\%) and after nightfall (66\%). Our findings for Indianapolis do not exactly align with prior research on killed in the line of duty homicides or homicides more generally (Cheatwood, 1988). Indeed, recent LEOKA data identify December as the deadliest month and Thursdays as the most frequent day of the week in which police homicides occur in the United States (Federal Bureau of Investigation, 2015).

\section{[INSERT TABLE 2 ABOUT HERE]}

For location, researchers found the majority of all police officer deaths occurred outdoors (75\%). More specifically, 54 percent occurred in a public street or an alley, with traffic-related incidents contributing to the high number of the outside deaths. When limited to felonious deaths, more than 41 percent of fatal felonious incidents occurred in a public street or alley. In the unusual killing of Officer Schoen described above, the officer was actually killed in front of his home.

\footnotetext{
${ }^{12}$ The pre-1900 incidents were treated as outliers for the 'average number of days between incidents' analysis and removed $(n=3)$ from this analysis only.
} 
Another 33 percent of felonious line of duty deaths occurred in residences. As discussed more below, the circumstances of these homicides varied from officers breaking up illegal craps games to responding to domestic violence calls and serving arrest warrants.

\section{[INSERT TABLE 3 ABOUT HERE]}

\section{Victim (Officer Characteristics)}

Turning to victim characteristics, the majority of officers killed in the line of duty (both felonious and accidental) were white males (Table 4). Only one female was killed in the line of duty and it was traffic related (i.e., not felonious). These figures are consistent with national trends, as it remains rare for a female officer to be killed in the line of duty (Federal Bureau of Investigation, 2015). Only five of the 68 Indianapolis officers killed were non-white (7.4\%), specifically black. All of the black officers were killed in felonious incidents from as early as 1922 to the last one occurring in 1976. Officer William Whitfield was the first black officer killed in Indianapolis. As a patrol officer, he was assigned to a predominantly white neighborhood and was killed by white suspect amid suspicions of racial motivation. No suspect was ever identified and few details about his murder are publicly available. Attributed no honors for his service, Whitfield was buried in an unmarked grave until 1998 when officers took up a collection to purchase him a headstone (Gill, 1988; "Slain officer finally receives fitting tribute,"). As for age, officers killed in the line of duty were as young as 23 with a mean age of approximately 38 years ( $\mathrm{sd}=10$ years). The oldest officer killed was a 76-year-old former detective who had been shot in the foot while on duty 25 years earlier. He died of complications related to surgery on his previously wounded foot.

[INSERT TABLE 4 ABOUT HERE] 
We were also able to capture the amount of time officers served the department prior to their deaths for all but two of the officers (Officer Dolby and Officer Irish, early 1900s). We discovered that the average time served was nine years. In one case, an officer was killed just 15 days after joining the department. Our findings align with national data, which indicate the majority of feloniously killed officers had served between six and 10 years at the time of their death (Federal Bureau of Investigation, 2015), as well as with previous research on police killed in the line of duty (Brown \& Langan, 2001; Geller \& Scott, 1992; Margarita, 1980b). The majority of officers held the rank of patrol officer or detective ${ }^{13}$ at the time of their death $(76.5 \%)$. Thirteen (19.1\%) held the rank of sergeant or lieutenant. In addition, two command staff-level officers were killed, one major (MCSD) and one inspector (IPD), the second highest ranking officer in the department. We also found 82 percent $(n=56)$ of officers killed in the line of duty were married and 59 percent had surviving children.

Focusing on the felonious line of duty death findings shown in Table 5, nearly 96 percent of homicide victims died of gunshot wounds. Of those firearm-related officer deaths, supplemental analyses indicated 72 percent involved handguns and 20 percent involved long guns. ${ }^{14}$ Archival data also allow us to examine accidental officer deaths more closely, revealing one "friendly fire" death or accidental shooting. In 1915, an officer accidentally shot his partner, Officer Elmer Anderson, as they dismounted their motorcycles. The officer was attempting to shoot at a 'mad dog' reportedly threatening the neighborhood. Over time, law enforcement training incorporated numerous officer safety principles in an attempt to prevent such friendly fire accidents (e.g., the tactical 'V', contact and cover). Since 1915, Indianapolis officers have not experienced a friendly fire line of duty death.

\footnotetext{
${ }^{13}$ Patrol officer and detective are the same rank.

14 There were three weapons $(8 \%)$ where the detail about the firearms could not be ascertained.
} 
With expanded technology, like the widespread availability of electricity and then motorised transportation, came other risks to police officers. In one 1906 death, Officer Dolby was killed by a surge of electricity as he attempted to use one of the department's call-in boxes installed in the city around the turn-of-the- $20^{\text {th }}$ century. Several other officers were shocked that day but survived. News reports suggested a storm that morning likely contributed to his accidental death. Other Indianapolis officers have also died by electrocution. In 1911, Officer Barrows died after attempting to move a downed live wire after a storm. Fortunately, advances in electrical infrastructures and communication systems, as well as significant advances in the provision of utility services, have saved officers from electrocution in more recent times.

Although there were no police deaths related to officers on either bicycles or horses, the introduction of motorcycles to the department in the 1920s proved deadly for at least seven officers (all but one occurred prior to 1965). The death of Officer Reilly (killed in 1942), who was killed on his motorcycle while trying to pass a car, is one example of such a case. In 1967, certain federal safety programs and highway construction funds became accessible only to states that enacted motorcycle helmet use laws. That year, Indiana passed a universal helmet law, though it was repealed ten years later. While there is photographic evidence supporting the use of helmets as early as 1961, police department records do not indicate when helmets became required equipment for Indianapolis motorcycle officers. ${ }^{15}$

\section{[INSERT TABLE 5 ABOUT HERE]}

As Indianapolis grew over time, so did the city's volume of traffic and the dangers to police officers on the roadways. Archival data show two Indianapolis officers were killed in separate incidents while directing traffic (Officer Foster in 1947 and Officer Reifeis in 1953), while Officers Lacy

\footnotetext{
${ }^{15}$ http://www.impdphotography.com/Historical-Police-Photography/Historical-Images/i-QvDkqrq
} 
and Ernest were killed accidental vehicle collisions (Table 5). Most recently, two officers were killed in separate automobile collisions in 1983. Officer Kortepeter's patrol car collided head on with a truck containing two fleeing robbery suspects. A drunk driver hit and killed Officer Hawkins, the only female officer killed in the line of duty, as she was responding to an unrelated call for service. Again, modern training and regulations are in place to try and prevent such line of duty deaths on Indianapolis' roads and highways. For instance, the Occupational Safety and Health Administration (OSHA) has set visibility guidelines (i.e., for clothing and signaling devices) for all workers, including police officers, who are directing traffic in an effort to improve safety and reduce deaths. Officers also regularly receive driver training (e.g., Emergency Vehicle Operators Course) and are subject to seat belt laws, though studies have shown that between 1980 to 2008 only 45 percent of officers killed in vehicle crashes in the United States were wearing their seat belts (Noh, 2011).

Examining the situated circumstances of line of duty deaths, we found the most common situations leading to a felonious death for Indianapolis officers were disturbance calls ${ }^{16}(\mathrm{n}=11)$ and investigations of suspicious persons/circumstances $(n=10)$ (see Table 6). This finding is in contrast to national data on line of duty deaths, which indicate arrest situations are the deadliest situations for officers (Federal Bureau of Investigation, 2015).

\section{[INSERT TABLE 6 ABOUT HERE]}

\footnotetext{
${ }^{16}$ According to the LEOKA definitions, a disturbance involves "[a] breach of the peace type of circumstance resulting in a call for law enforcement to respond. Examples include, but are not limited to: curfew violations, disorderly persons, drinking in public, fights, fireworks violations, gambling in public space, persons under the influence, landlord/tenant disputes, loitering, loud noise of any type (excluding animal disturbance complaints by a citizen), littering, nuisance complaints, prostitution offenses, trespassing or unwanted guests, vagrancy violations, and verbal altercations" while an investigation is "[a]n activity where an officer's intent is to investigate an unusual occurrence, an out-of-the-ordinary condition, or a suspicious person or circumstance. The main difference being what instigated the circumstance - a call for service or officer self-initiated activity. For our purposes we included domestic disturbances with disturbances as they are defined as a specific "breach of the peace." See https://ucr.fbi.gov/leoka/2015/resource-pages/leoka-definitions_-2015.
} 
Two of the earliest deaths recorded by the police department illuminate the nature of risks faced by officers prior to the turn-of-the- $19^{\text {th }}$-century. In one early case, off-duty Officer Burns was beckoned to a brawl at a local saloon near his home. Arriving in plain clothes, an inebriated man shot him instantly in the chest as he walked through the door. Years later, Officer Ware was called to a saloon where drunken members of a known gang were loitering and fighting with one another. After physically struggling with one of the gang members, Officer Ware was shot in the temple, dying instantly and becoming the second police officer in Indianapolis killed while on duty.

With the turn-of-the-century came fewer line of duty deaths occurring in the context of barroom brawl situations. The social and cultural landscapes of Indianapolis evolved, and the risks to officers also changed. In particular, the threats of drunken violence shifted to violence in the home between intimates and family members. Two examples illustrate the elevated risk faced by officers when responding to such calls also involving armed suspects. In 1975, Officer Greene and a rookie officer responded to a 911 call regarding a domestic disturbance, wherein the suspect had reportedly shot his nephew. When police arrived, Officer Greene was shot while checking on the shooter. Two other responding officers subsequently shot and killed the suspect who died at the scene. In another Indianapolis domestic disturbance nearly 40 years later, Officer Bradway responded to a disturbance call at an apartment complex located in the Northwest part of the city. The suspect had already fired his gun and was holding a woman hostage. Sensing the woman's life was in danger, Officer Bradway kicked in the door and was shot several times, though not before shooting the suspect. Minutes later, another officer arrived and killed the suspect. In contrast, some homicides involving suspicious persons or circumstances occurred in locations other than private residences. For example, Officer Louden was shot and killed by a suspected 
drug store burglar in 1923, and two deputies, Deputies Baker and Morris, were shot and killed while responding to a robbery at a clothing store in 1981 .

Our archival data also allowed us to examine in more depth the situated processes of line of duty deaths, or how homicidal events are initiated, escalated, and ended. For most cases, we were able to reconstruct detailed homicide narratives based on reported witness testimony, fellow officer accounts, and court documents.

\section{[INSERT TABLE 7 ABOUT HERE]}

Not surprisingly, we found most events began abruptly with the death of an officer. The majority of officers killed in felonious homicides had no warning before being shot, as illustrated by the death of Officer Hull who was shot and killed in 1920 upon leading officers into an Indianapolis home known to host illegal gambling (Table 7). In another felonious homicide over 50 years later, Deputy Settles was shot and killed when he responded to a bank robbery in progress in 1972. In this type of case, officers could expect an increased risk to their safety.

In other cases, however, homicide situations were initiated by gunfire during routine police work. For instance, Officer Moore was shot in 2011 during a routine traffic stop as he approached the vehicle. Similarly, in 1961, Officer Bryne was killed while conducting a traffic stop (i.e., investigating suspicious person) of a suspect thought to be involved in a tavern break-in. In another line of duty death, Officer DeRossette was shot and killed in 1917 during routine investigative activity - performing a search of two juveniles. Another potentially dangerous type of situation for officers are ambushes. Not unlike other examples wherein the fatal attack on officers was a surprise, ambushes are situations where an offender lies in wait to attack an officer, applying to approximately 13 percent of the felonious deaths in this study. Ambush-style attacks typically involved officers entering residences or buildings, while other police homicides were instigated 
by physical struggles between police officers $(6.5 \%)$ and offenders and the use of non-lethal force against offenders (2.2\%). In 1951, Officer Snorden, a black officer, and his partner responded to the house of a suspect who had called the police declaring he had already killed someone. Upon arrival, the suspect shot the two officers, Snorden fatally. Other responding officers later killed the shooter.

We also found several categories of behaviors appearing to possibly escalate already tense situations into deadly ones for officers (Table 8). In particular, we found nearly 29 percent of police homicides escalated following a clear show of force by officers. For instance, Officer Manley was killed in 1974 when he was shot after arriving at the scene of a drug store robbery with his weapon drawn.

\section{[INSERT TABLE 8 ABOUT HERE]}

Other occurrences turned deadly when third parties entered into volatile situations or when officers and offenders struggled to retrieve weapons. As many cases were initiated by unforeseen attacks, is it not surprising that in over 50 percent of police homicides it was impossible to discern a particular act by either the police or offender that served to escalate situations into lethal outcomes.

In addition to how line of duty events escalated, we were also interested in how the incidents most commonly concluded (Table 9). Our analysis showed in most instances, line of duty death situations concluded with Indianapolis police officers capturing offenders. The majority of suspects $(41.3 \%)$ were captured or surrendered within 24 hours of the incident with 61 percent of suspects eventually being captured. The next most common ending of police homicides was the killing of offenders by police (28.3\%).

[INSERT TABLE 9 ABOUT HERE] 
Another nearly 20 percent of offenders were captured by police one or more days after a fatal attack on a police officer. Suspects were usually on the lam for only a matter of days. For example, in 1965, Officer Graham was transporting a burglar down to a station holding area when he began to struggle with the officer, eventually taking his service revolver and fatally wounding him. The suspect was on the run for two days before being captured. Several years later, Deputy Settles was shot and killed responding to a silent bank robbery alarm. The two suspects fled and one was arrested the next day; the other surrendered a few days later. In another incident occurring forty years later, Deputy Baker was shot and killed in a rolling gun fight. One suspect was killed the day of the incident but the shooter was not captured until the next day. Though the majority of offenders were either killed or arrested very soon after the officer was killed in a felonious attack, approximately 9 percent $(n=4)$ of cases involved one or more offenders who were never captured or killed, three of which occurred in the 1920s.

\section{Suspect Characteristics}

Researchers were able to identify 57 suspects in 42 felonious homicides and traffic-related deaths (see Table 10). Only 11 of the incidents involved more than one suspect. The majority of identified suspects $(n=54)$ were related to felonious killings, although three individuals were identified as accidentally killing a police officer (see Table 10). All but two of the suspects (3.5\%) were males. Thirty-seven percent of suspects were white $(n=21)$ and $40 \%$ were non-white $(n=23)$, while race could not be determined for the remaining 23 percent of suspects $(n=13)$.

Fourteen (26\%) of the 54 felonious incident suspects died at the scene or in a later incident with police. Five $(9.4 \%)$ of the felonious incident suspects have been executed by the State of Indiana and one died in prison. As of the writing of this article, three (5.6\%) suspects still remain in custody, while one of them awaits trial. 


\section{Discussion and Conclusion}

In this study, we sought to explore the nature of line of duty deaths within the context of how urban development and technological advances adopted by law enforcement may have shaped police work over the course of the $20^{\text {th }}$ century. Key findings were discussed within these broader themes to demonstrate how such changes can simultaneously make police work more effective and create additional risks to police officer safety. In particular, we considered how the introduction of new modes of motorised transportation provided Indianapolis officers more protection than foot patrol, horse patrol, or bicycle patrol, while simultaneously allowing them to respond more rapidly to crimes and other emergencies. At the same time, it is also possible to link the adoption of motorcycles and automobiles to officer deaths in the line of duty. Of all accidental line of duty deaths, nearly 70 percent of officers were killed as a result of motorcycle and automobile accidents. Moreover, when considering the circumstances of accidental officer deaths, we found over 40 percent involved traffic stops or pursuits. While officers were able to arrive at crimes in progress more quickly with motorised transportation, it is also the case that police were more likely to be killed by armed suspects upon arrival.

We can draw similar conclusions about the adoption of more sophisticated communication systems. While call boxes installed in the early 1900s allowed officers to more efficiently communicate with headquarters, we found 11 percent of accidental officer deaths were the result of being electrocuted when using call boxes. It was less possible for us to effectively link advances in the sophistication or availability of firearms over the $20^{\text {th }}$ century to line of duty deaths, as we found 96 percent of all felonious deaths, stemming back to the late 1800 s, were committed with firearms. Nonetheless, our analysis of case narratives revealed the circumstances in which firearms, usually handguns, were used against officers. As young, working-class males who 
migrated to Indianapolis for industrial jobs settled down, we found officers were less frequently killed while intervening in drunken brawls and more likely to be killed by lone gunman during routine traffic stops or when responding to domestic disturbances.

Our findings also support those of prior research in several ways. In particular, we found Indianapolis police officers are most commonly killed by armed suspects, are under the age of 40, and have less than 10 years of experience on the department when killed. Considering additional event attributes expanded what is known about how line of duty deaths are initiated, escalated, and concluded. We found the vast majority (76\%) of incidents were initiated not by physical struggles or in response to non-lethal force, but instead by unsuspecting officers ruthlessly being shot. While we were unable to identity escalating factors in most cases, officers' own shows of force escalated risky encounters into deadly outcomes in nearly 30 percent of cases.

It is our hope a more comprehensive understanding of line of duty deaths can also illuminate avenues for increasing police officer safety. While our recommendations are not necessarily original, we believe they are supported by the results of our analyses. First, our findings clearly indicate the use of vehicles, both motorcycles and automobiles, present substantial risks to police officers. In addition to more training and following basic safety guidelines for operating vehicles (e.g., wearing seatbelts), reducing or eliminating motorcycle patrols and restricting officers from engaging in high-speed pursuits, which have been found to result in injuries to officers, vehicle occupants, or bystanders in nearly half of all pursuit crashes (Alpert et al., 2006), could increase officer safety. Second, responding to calls involving armed suspects is one of the most dangerous aspects of police work, and nearly all felonious line of duty officer deaths in Indianapolis and the rest of the country involved firearms. The benefits of protective body armor for reducing officer fatalities has been substantiated and shown to be well worth the 
additional costs of purchasing new equipment (LaTourrette, 2010). However, resources should also be allocated to building enhanced intelligence gathering systems that allow officers to efficiently access information in the field to identify high-risk people and places. Officers must have access to the most up-to-date information on individuals who are under correctional supervision and who have made prior threats against the police. Agencies should also invest in increased communication systems and organizational integration within and across police departments (e.g., taskforces) and other criminal justice agencies so intelligence can be more seamlessly shared.

Our study is of course not without limitations. This is a single case study in one large, Midwestern city. Research has shown police officer killings vary by region (Bristow, 1963; Cardarelli, 1968; Chapman, 1986; Edwards, 1995; Fridell \& Pate, 1997; Geller \& Scott, 1992; Robert J. Kaminski, 2004; Robert J Kaminski, 2008; Robert J. Kaminski et al., 2000; Lester, 1978a; Little, 1984; Pinizzotto \& Davis, 1992; Pinizzotto et al., 1997, 2006) and therefore our results are most likely specific to the region. The sample size is small and while patterns do emerge, the representativeness of the findings is limited. The inclusion of felonious assaults, as also suggested by Brandl (1996), would increase the reliability and validity of the findings. And, since most violence against police officers is firearm-related, perhaps police officer suicides by firearm should be included as well. Both could serve to inform training and prevention conducted by police departments.

\section{Conclusion}

Our study examined the nature of police killed in the line of duty incidents spanning the entire history of a single, large metropolitan police department. Based on data collected from agency records, news media, books, and other available sources, several incident-, victim-, and 
offender-level variables were examined to understand the patterned nature of felonious and accidental police deaths occurring between the late 1800 s to the early 2010 s. Data culled from multiple sources made it possible to triangulate several data points in such a way as to determine the most accurate details when constructing line of duty event narratives. Though previous studies have researched police homicides and accidental deaths using official crime statistics, we suggest relying on non-traditional archival data has several advantages for advancing our understanding of line of duty deaths. It also allowed us to explore officer deaths more holistically, from background factors, to violent transactions, and incident aftermaths, all of which contribute to deadly outcomes for law enforcement. Furthermore, the richness and depth of these alternative data also allowed us to more fully consider the sociohistorical contexts of certain police deaths, including how socioeconomic conditions and the adoption of new technologies shaped the dangers of police work. This study found police homicide in Indianapolis was most likely to occur in the 1920s and 1970s, during investigations of disturbances and suspicious persons/circumstances, and most always led to the surrender, capture, or death of offenders. Based on our analysis of several unexplored variables, we found nearly 40 percent of incidents were escalated by police shows of force and the introduction of third parties to already tense situations. We suggest that drawing from multiple sources of data and including situational variables such as these can inform law enforcement training and practices. 


\section{References}

Adler, J. (1999). The negro would be more than an angel to withstand such treatment: African American homicide in Chicago, 1875-1910. In M. A. Bellesiles (Ed.), Lethal imagination: Violence and brutality in American history (pp. 295-314). New York: New York University Press.

Anderson, E. (1990). Streetwise: race, class, and change in an urban community. Chicago: The University of Chicago Press.

Batton, C., \& Wilson, S. (2006). Police murders an examination of historical trends in the killing of law enforcement officers in the United States, 1947 to 1998. Homicide Studies, 10(2), 79-97. doi: 10.1177/1088767905285449

Beeghley, L. (2004). Homicide: A sociological explanation. Lanham, MD: Rowman \& Littlefield Publishers.

Brandl, S. G. (1996). In the line of duty: A descriptive analysis of police assaults and accidents. Journal of Criminal Justice, 24(3), 255-264. doi: 10.1016/0047-2352(96)00007-4

Bridges, C. K., \& Hegner, Q. J. (1976). Peace Officers Killed and Assaulted in California, 1974. Sacramento, CA: California Department of Justice.

Bristow, A. P. (1963). Police officer shootings: A tactical evaluation. The Journal of Criminal Law, Criminology, and Police Science, 54(1), 93-95. doi: 10.2307/1141144

Brown, J. M., \& Langan, P. A. (2001). Policing and homicide, 1976-98: Justifiable homicide by police, police officers murdered by felons. Washington, DC: US Department of Justice, Office of Justice Programs, Bureau of Justice Statistics.

Bureau of Labor Statistics, U.S. Department of Labor. (2015). National Census of Fatal Occupational Injuries in 2014. Washington, DC: Bureau of Labor Statistics, U.S. Department of Labor.

Cardarelli, A. P. (1968). An analysis of police killed by criminal action: 1961-1963. The Journal of Criminal Law, Criminology, and Police Science, 59(3), 447-453. doi: $10.2307 / 1141788$

Chapman, S. G. (1976). Police murders and effective countermeasures. Santa Cruz, CA: Davis Publishing Company.

Chapman, S. G. (1986). Cops, killers, and staying alive: The murder of police officers in America. Springfield, IL: Charles C Thomas Pub Ltd.

Chapman, S. G. (1998). Murdered on duty: The killing of police officers in America (2nd ed.). Springfield, IL: Charles C. Thomas, Publisher, Ltd.

Cheatwood, D. (1988). Is there a season for homicide? Criminology, 26(2), 287-306. doi: 10.1111/j.1745-9125.1988.tb00842.x

Chermak, S. M., Freilich, J. D., Parkin, W. S., \& Lynch, J. P. (2012). American terrorism and extremist crime data sources and selectivity bias: An investigation focusing on homicide events committed by far-right extremists. Journal of Quantitative Criminology, 28(1), 191-218. doi: 10.1007/s10940-011-9156-4

Chudacoff, H. P. (1999). The age of the bachelor: Creating an American subculture. Princeton, NJ: Princeton University Press.

City of Indianapolis. (2016). Indianapolis Metropolitan Police Department. Retrieved from http://www.indy.gov/eGov/City/DPS/IMPD/About/Pages/home.aspx

Cook, P. J. (1983). The influence of gun availability on violent crime patterns. Crime and Justice, 4, 49-89. doi: 10.1086/449086 
Edwards, T. D. (1995). Felonious killings of state police and highway patrol officers: A descriptive and comparative evaluation. American Journal of Police, 14(2), 89-105. doi: $10.1108 / 07358549510102776$

Federal Bureau of Investigation. (2013). Criminal Justice Information Services (CJIS) Division Uniform Crime Reporting Program (UCR). Retrieved from https://www.fbi.gov/aboutus/cjis/ucr/nibrs/summary-reporting-system-srs-user-manual

Federal Bureau of Investigation. (2015). Crime in the United States, 2014. Retrieved from https://www.fbi.gov/about-us/cjis/ucr/crime-in-the-u.s/2012/crime-in-the-u.s.2012/violent-crime/aggravated-assault

Federal Bureau of Investigation. (2016). Law enforcement officers killed and assaulted, 2014. Retrieved from https://www.fbi.gov/about-us/cjis/ucr/leoka/2014/resourcepages/officer criteria -2014

Fridell, L. A., \& Pate, A. M. (1997). Death on patrol: Killings of American law enforcement officers. In G. P. Alpert \& R. G. Dunham (Eds.), Critical issues in policing: Contemporary readings. Prospect Heights, IL: Waveland Press.

Garner, J., \& Clemmer, E. (1986). Danger to police in domestic disturbances-A new look. Washington, DC: U.S. Department of Justice, National Institute of Justice.

Geller, W. A., \& Karales, K. J. (1982). Shootings of and by Chicago police: Uncommon crises-Part II: Shootings of police, shooting correlates and control strategies. Journal of Criminal Law and Criminology, 73(1), 331-378

Geller, W. A., \& Scott, M. (1992). Deadly force: What we know: A practitioner's desk reference on police-involved shootings. Washington, DC: Police Executive Research Forum

Gill, K. (1988, December 4, 1988). IPD honors forgetten hero, The Indianapolis Recorder.

Gruenewald, J. A., \& Pridemore, W. A. (2009). Stability and change in homicide victim, offender, and event characteristics in Chicago, 1900 and 2000. Homicide Studies, 13(4), 355-384. doi: 10.1177/1088767909348587

Indianapolis Police Historical \& Educational Foundation. (2008). Indianapolis Police Department, 2006. Evansville, IN: M.T. Publishing Company, Inc.

Kaminski, R. J. (2004). The murder of police officers. New York: LFB Scholarly Publishing LLC.

Kaminski, R. J. (2008). Assessing the county-level structural covariates of police homicides. Homicide Studies, 12(4), 350-380. doi: 10.1177/1088767908323863

Kaminski, R. J., Jefferis, E. S., \& Chanhatasilpa, C. (2000). A spatial analysis of American police killed in the line of duty. In L. S. Turnbull, E. H. Hendrix \& B. D. Dent (Eds.), Atlas of crime: Mapping the criminal landscape (pp. 212-220). Westport, CT: Greenwood.

Kercher, C., Swedler, D. I., Pollack, K. M., \& Webster, D. W. (2013). Homicides of law enforcement officers responding to domestic disturbance calls. Injury Prevention, 19(5), 331-335. doi: 10.1136/injuryprev-2012-040723

King, W. R., \& Sanders, B. A. (1997). Nice guys finish last: A critical review of Killed in the Line of Duty. Policing: An International Journal of Police Strategies \& Management, 20(2), 392-407. doi: 10.1108/13639519710169207

Konstantin, D. N. (1984). Homicides of American law enforcement officers, 1978-1980. Justice Quarterly, 1(1), 29-45. doi: 10.1080/07418828400088021

Landis, J. R., \& Koch, G. G. (1977). The measurement of observer agreement for categorical data. Biometrics, 33(1), 159-174. doi: 10.2307/2529310 
LaTourrette, T. (2010). The life-saving effectiveness of body armor for police officers. Journal of Occupational and Environmental Hygiene, 7(10), 557-562. doi:

10.1080/15459624.2010.489798

Lester, D. (1978a). Predicting murder rates of police officers in urban areas. Police Law Quarterly, 7, 20-25

Lester, D. (1978b). A study of civilian-caused murders of police officers. International Journal of Criminology and Penology, 6(4), 373-378

Lester, D. (1984). The murder of police officers in American cities. Criminal Justice and Behavior, 11(1), 101-113. doi: 10.1177/0093854884011001005

Little, R. E. (1984). Cop-killing: A descriptive analysis of the problem. Police Studies: The International Review of Police Development, 7, 68-76

Margarita, M. (1980a). Killing the police: Myths and motives. The ANNALS of the American Academy of Political and Social Science, 452(1), 63-71. doi: $10.1177 / 000271628045200107$

Margarita, M. (1980b). Police as victims of violence. The Justice System Journal, 5(3), 218-233

Massey, D. S., \& Denton, N. A. (1993). American apartheid: Segregation and the making of the underclass. Cambridge, MA: Harvard University Press.

Monkkonen, E. H. (1992). History of urban police. Crime and Justice, 15, 547-580. doi: $10.1086 / 449201$

Noh, E. Y. (2011). Characteristics of Law Enforcement Officers' Fatalities in Motor Vehicle Crashes. Washington, DC: U.S. National Highway Traffic Safety Administration

Park, R. E., Burgess, E. W., \& McKenzie, R. D. (1984). The city. Chicago, IL: University of Chicago Press.

Parkin, W. S., \& Gruenewald, J. (2015). Open-source data and the study of homicide. Journal of Interpersonal Violence. doi: 10.1177/0886260515596145

Pinizzotto, A. J., \& Davis, E. F. (1992). Cop killers and their victims. Washington, DC. Retrieved from FBI Law Enforcement Bulletin.

Pinizzotto, A. J., Davis, E. F., \& Miller III, C. E. (1997). In the line of fire: A study of selected felonious assaults on law enforcement officers. Washingon, DC: U.S. Department of Justice.

Pinizzotto, A. J., Davis, E. F., \& Miller III, C. E. (2006). Violent encounters: A study of felonious assaults on our nation's law enforcement officers. Washington, DC: U.S. Department of Justice.

Quinet, K. D., Bordua, D. J., \& Lassiter, W. (1997). Line of duty police deaths: A paradoxical trend in felonious homicides in the United States. Policing and Society, 6(4), 283-296. doi: 10.1080/10439463.1997.9964758

Reaves, B. A. (2015). Local Police Departments, 2013: Personnel, Policies, and Practices (NCJ 248677). Washington, DC: U.S. Department of Justice, Office of Justice Programs, Bureau of Justice Statistics.

Ritsema, J., \& Spears, M. T. (2015). Indianapolis police officers killed in the line of duty: Final Resting Places.

Roth, R. (2012). American homicide. Cambridge, MA: Harvard University Press.

Rubinstein, J. (1973). City police. New York: Ballantine Books.

Sacco, V. F., \& Kennedy, L. W. (2002). The criminal event: Perspectives in space and time (2nd ed.). Belmont, CA: Wadsworth. 
Shaw, C., \& McKay, H. (1942). Juvenile delinquency and urban areas. Chicago: University of Chicago Press.

Shihadeh, E. S., \& Ousey, G. C. (1998). Industrial restructuring and violence: The link between entry-level jobs, economic deprivation, and Black and White homicide. Social Forces, 77(1), 185-206. doi: 10.2307/3006014

Slain officer finally receives fitting tribute. (December 1, 1988). The Indianapolis Star.

Tenuth, J. (2004). Indianapolis: A Circle City history. Charleston, SC: Arcadia Publishing.

Tucker-Gail, K. A., Selman, D., Kobolt, J. R., \& Hill, T. (2010). Felonious line-of-duty officer deaths (1995-1999): The impact of tenure and age. International Journal of Police Science \& Management, 12(1), 119-133. doi: 10.1350/ijps.2010.12.1.157

Uchida, C. D., \& Brooks, L. W. (1988). Violence against the police: Assaults on Baltimore County Police, 1984-86, Final Report. College Park, MD: Institute of Criminology and Criminal Justice, University of Maryland.

United States Census Bureau. (2015). QuickFacts Beta. Retrieved from http://www.census.gov/quickfacts/table/PST045214/1836003,00

Walker, S. (1977). A critical history of police reform. Lexington, MA: Lexington Books.

Weaver, G. S. (2002). Firearm deaths, gun availability, and legal regulatory changes: Suggestions from the data. The Journal of Criminal Law and Criminology 92(3/4), 823842. doi: $10.2307 / 1144246$

Wilbanks, W. (1984). Murder in Miami: An analysis of homicide patterns and trends in Dade County (Miami) Florida, 1917-1983. Lanham, MD: University Press of America.

Wilbanks, W. (1994). Cops killed and cop-killers: An historical perspective. American Journal of Police, 13(1), 31-49

Wilson, S., \& Batton, C. (2004). Historical trends in police murders, 1947-1998. In V. Pottie Bunge, C. R. Block \& M. Lane (Eds.), Linking Data to Practice in Violence and Homicide Prevention. Chicago, IL: HRWG Publications.

Wilson, W. J. (1996). When work disappears: The world of the new urban poor. New York: Alfred A. Knopf, Inc.

Zimring, F. E., \& Arsiniega, B. (2015). Trends in killing of and by police: A preliminary analysis Commentaries. Ohio State Journal of Criminal Law, 13(1), 247-264 
Tables

Table 1. Decade and number of fatal incidents

\begin{tabular}{|l|c|c|c|c|}
\hline & Felonious & Accidental & $\mathrm{n}$ & $\%$ \\
\hline $1870^{*}$ & 1 & 0 & 1 & 1.5 \\
\hline 1880 & 1 & 0 & 1 & 1.5 \\
\hline 1890 & 1 & 0 & 1 & 1.5 \\
\hline 1900 & 2 & 2 & 4 & 5.9 \\
\hline 1910 & 5 & 3 & 8 & 11.8 \\
\hline $\mathbf{1 9 2 0}$ & $\mathbf{7}$ & $\mathbf{2}$ & $\mathbf{9}$ & $\mathbf{1 3 . 2}$ \\
\hline 1930 & 4 & 1 & 5 & 7.4 \\
\hline 1940 & 1 & 4 & 5 & 7.4 \\
\hline 1950 & 4 & 3 & 7 & 10.3 \\
\hline 1960 & 2 & 1 & 3 & 4.4 \\
\hline $\mathbf{1 9 7 0}$ & $\mathbf{8}$ & $\mathbf{2}$ & $\mathbf{1 0}$ & $\mathbf{1 4 . 7}$ \\
\hline 1980 & 6 & 1 & 7 & 10.3 \\
\hline 1990 & 0 & 2 & 2 & 2.9 \\
\hline 2000 & 2 & 0 & 2 & 2.9 \\
\hline 2010 & 3 & 0 & 3 & 4.4 \\
\hline Total & 47 & 21 & 68 & 100.0 \\
\hline
\end{tabular}

* Incident occurred in 1872 but officer did succumb to his wounds until 1922.

Table 2. Incident month and day of week

\begin{tabular}{|c|c|c|c|c|c|c|c|c|c|c|c|c|c|c|c|c|}
\hline & \multirow{2}{*}{\multicolumn{2}{|c|}{$\frac{\text { Mon }}{\mathbf{n}}$}} & \multirow{2}{*}{\multicolumn{2}{|c|}{$\begin{array}{c}\text { Tue } \\
\mathrm{n}\end{array}$}} & \multirow{2}{*}{\multicolumn{2}{|c|}{$\frac{\text { Wed }}{\mathbf{n}}$}} & \multirow{2}{*}{\multicolumn{2}{|c|}{$\begin{array}{c}\text { Thu } \\
\text { n }\end{array}$}} & \multirow{2}{*}{\multicolumn{2}{|c|}{ Fri }} & \multirow{2}{*}{\multicolumn{2}{|c|}{$\frac{\text { Sat }}{\mathbf{n}}$}} & \multirow{2}{*}{\multicolumn{2}{|c|}{ Sun }} & \multicolumn{2}{|c|}{ Total } \\
\hline & & & & & & & & & & & & & & & $\mathbf{n}$ & $\%$ \\
\hline Jan & & 0 & & 1 & & 2 & & 2 & & 2 & & 2 & & 1 & 10 & 14.7 \\
\hline Feb & & 0 & & 2 & & 0 & & 1 & & 1 & & 0 & & 0 & 4 & 5.9 \\
\hline Mar & & 0 & & 2 & & 0 & & 2 & & 1 & & 2 & & 0 & 7 & 10.6 \\
\hline Apr & & 1 & & 2 & & 0 & & 1 & & 0 & & 0 & & 1 & 5 & 7.4 \\
\hline May & & 0 & & 0 & & 0 & & 0 & & 1 & & 1 & & 1 & 3 & 4.4 \\
\hline Jun & & 0 & & 1 & & 1 & & 1 & & 1 & & 1 & & 1 & 6 & 8.8 \\
\hline Jul & & 0 & & 3 & & 1 & & 0 & & 2 & & 2 & & 0 & 8 & 11.8 \\
\hline Aug & & 1 & & 1 & & 1 & & 0 & & 1 & & 0 & & 1 & 5 & 7.4 \\
\hline Sep & & 1 & & 0 & & 1 & & 0 & & 1 & & 1 & & 2 & 6 & 8.8 \\
\hline Oct & & 0 & & 3 & & 0 & & 0 & & 1 & & 1 & & 0 & 5 & 7.4 \\
\hline Nov & & 0 & & 2 & & 0 & & 1 & & 0 & & 0 & & 0 & 3 & 4.4 \\
\hline Dec & & 0 & & 0 & & 1 & & 2 & & 0 & & 2 & & 1 & 6 & 8.8 \\
\hline & \begin{tabular}{|l|}
$\mathrm{n}$ \\
\end{tabular} & $\%$ & $n$ & $\%$ & $\mathrm{n}$ & $\%$ & $\mathrm{n}$ & $\%$ & $\mathrm{n}$ & $\%$ & $\mathrm{n}$ & $\%$ & $\mathrm{n}$ & $\%$ & $\mathrm{n}$ & $\%$ \\
\hline Total & 3 & 4.4 & 17 & \begin{tabular}{|l|l|}
25.0 \\
\end{tabular} & 7 & 10.3 & 10 & 14.7 & 11 & 16.2 & 12 & 17.6 & 8 & 11.8 & 68 & 100.0 \\
\hline
\end{tabular}


Tables

Table 3 Incident premise type (felonious)

\begin{tabular}{|l|l|l|}
\hline & $\mathrm{n}$ & $\%$ \\
\hline Business & 9 & 19.5 \\
\hline Residence & 15 & 32.6 \\
\hline Public Street/Alley & 19 & 41.3 \\
\hline Vehicle & 1 & 2.2 \\
\hline Other & 1 & 2.2 \\
\hline Unknown & 1 & 2.2 \\
\hline Total & 46 & 100 \\
\hline
\end{tabular}

Table 4. Officer race and gender

\begin{tabular}{|l|l|l|l|l|l|l|}
\hline & \multicolumn{2}{|l|}{ Female } & \multicolumn{2}{l|}{ Male } & \multicolumn{2}{l|}{ Total } \\
\hline & $\mathrm{n}$ & $\%$ & $\mathrm{n}$ & $\%$ & $\mathrm{n}$ & $\%$ \\
\hline Non-White & 0 & 0.0 & 5 & 7.5 & 5 & 7.4 \\
\hline White & 1 & 100.0 & 62 & 92.5 & 53 & 92.6 \\
\hline Total & 1 & 1.5 & 67 & 98.5 & 68 & 100.0 \\
\hline
\end{tabular}

Table 5. Victim (Officer) Method of death and detail

\begin{tabular}{|l|l|l|l|l|l|l|}
\hline \multirow{2}{*}{} & \multicolumn{2}{|l|}{ Homicide } & \multicolumn{2}{l|}{ Accidental } & \multicolumn{2}{l|}{ Total } \\
\cline { 2 - 8 } & $\mathrm{n}$ & $\%$ & $\mathrm{n}$ & $\%$ & $\mathrm{n}$ & $\%$ \\
\hline Gunshot & 44 & 95.7 & 1 & 5.3 & 45 & 66.2 \\
\hline Electrocution & 0 & 0.0 & 2 & 10.5 & 2 & 2.9 \\
\hline Motorcycle accident & 0 & 0.0 & 7 & 36.8 & 7 & 10.3 \\
\hline Automobile accident & 2 & 4.3 & 7 & 36.8 & 9 & 13.2 \\
\hline Other* & 0 & 0.0 & 5 & 26.3 & 5 & 7.4 \\
\hline Total & 46 & 67.6 & 22 & 32.4 & 68 & 100.0 \\
\hline
\end{tabular}

*includes falls, heat stroke, and other fatal injuries. 
Table 6. All line of duty deaths, 1882-2014

\begin{tabular}{|l|l|l|l|l|l|l|}
\hline & \multicolumn{2}{|l|}{ Felonious } & \multicolumn{2}{l|}{ Accidental } & \multicolumn{2}{l|}{ Total } \\
\hline & $\mathbf{n}$ & $\mathbf{\%}$ & $\mathbf{n}$ & $\mathbf{\%}$ & $\mathbf{n}$ & $\mathbf{\%}$ \\
\hline Arrest situation & 4 & 8.7 & 0 & 0.0 & 4 & 5.9 \\
\hline Ambush situation & 2 & 4.3 & 0 & 0.0 & 2 & 2.9 \\
\hline Traffic pursuit/stop & 5 & 10.9 & 9 & 40.9 & 14 & 20.6 \\
\hline Disturbance call & $\mathbf{1 1}$ & $\mathbf{2 3 . 9}$ & $\mathbf{1}$ & $\mathbf{4 . 5}$ & $\mathbf{1 2}$ & $\mathbf{1 7 . 6}$ \\
\hline Investigation suspicious persons/circumstances & $\mathbf{1 0}$ & $\mathbf{2 1 . 7}$ & $\mathbf{1}$ & $\mathbf{4 . 5}$ & $\mathbf{1 1}$ & $\mathbf{1 6 . 2}$ \\
\hline Tactical situation & 4 & 8.7 & 0 & 0.0 & 4 & 5.9 \\
\hline Handling, transporting, custody of prisoner & 2 & 4.3 & 0 & 0.0 & 2 & 2.9 \\
\hline $\begin{array}{l}\text { Investigative activity (surveillance, search, } \\
\text { interview, etc.) }\end{array}$ & 4 & 8.7 & 1 & 4.5 & 4 & 7.4 \\
\hline Handling persons with mental illness & 1 & 2.2 & 0 & 0.0 & 1 & 1.5 \\
\hline All others & 3 & 6.5 & 10 & 45.5 & 13 & 19.1 \\
\hline Total & 46 & 67.6 & 22 & 32.4 & 68 & 100.0 \\
\hline
\end{tabular}

Table 7. Initiation of Police Homicide Events

\begin{tabular}{|l|c|c|}
\hline & $\mathbf{n}$ & $\mathbf{\%}$ \\
\hline Offender shooting at officers & $\mathbf{3 5}$ & $\mathbf{7 6 . 1}$ \\
\hline Ambush attack (Lying in Wait) & 6 & 13.0 \\
\hline Physical struggle & 3 & 6.5 \\
\hline Response to officer's non-lethal force & 1 & 2.2 \\
\hline NA & 1 & 2.2 \\
\hline Total & 46 & 100 \\
\hline
\end{tabular}

Table 8. Escalation of Police Homicides

\begin{tabular}{|l|c|c|}
\hline & n & \% \\
\hline No known escalating factors & $\mathbf{2 5}$ & $\mathbf{5 4 . 3}$ \\
\hline Show of force by police & 13 & 28.3 \\
\hline Introduction of a third party & 5 & 10.9 \\
\hline Struggle over a weapon & 2 & 4.3 \\
\hline NA & 1 & 2.2 \\
\hline Total & $\mathbf{4 6}$ & $\mathbf{1 0 0}$ \\
\hline
\end{tabular}




\section{Tables}

Table 9. Conclusion of police homicide events

\begin{tabular}{|l|c|c|}
\hline & $\mathbf{n}$ & $\mathbf{\%}$ \\
\hline Near immediate surrender or capture & $\mathbf{1 9}$ & $\mathbf{4 1 . 3}$ \\
\hline Offender killed by police & 13 & 28.3 \\
\hline Offender captured (1 or more days) after incident & 9 & 19.8 \\
\hline Offender never captured & 4 & 8.7 \\
\hline Offender committed suicide & 1 & 2.2 \\
\hline Total & $\mathbf{4 6}$ & $\mathbf{1 0 0}$ \\
\hline
\end{tabular}

Table 10. Suspect count and incident type

\begin{tabular}{|c|c|c|c|c|c|c|c|c|}
\hline & \multicolumn{2}{|c|}{ Felonious } & \multicolumn{2}{|c|}{ Traffic-related } & \multicolumn{2}{|c|}{ Accidental } & \multicolumn{2}{|c|}{ Total } \\
\hline & $\mathrm{n}$ & $\%$ & $\mathrm{n}$ & $\%$ & $\mathrm{n}$ & $\%$ & $\mathrm{n}$ & $\%$ \\
\hline 1 suspect & 28 & 71.8 & 3 & 100.0 & 0 & 0.0 & 31 & 73.8 \\
\hline 2 suspects & 8 & 20.5 & 0 & 0.0 & 0 & 0.0 & 8 & 19.0 \\
\hline 3 suspects & 2 & 5.1 & 0 & 0.0 & 0 & 0.0 & 2 & 4.8 \\
\hline 4 suspects & 1 & 2.6 & 0 & 0.0 & 0 & 0.0 & 1 & 2.4 \\
\hline Total & 39 & 92.9 & 3 & 7.1 & 0 & 0.0 & 42 & 100.0 \\
\hline
\end{tabular}


Appendix A. Indianapolis Officers Killed in the Line of Duty

\begin{tabular}{|c|c|c|c|c|c|c|c|c|}
\hline Incident ID & Last Name & First Name & Incident Date & Date of Death & Incident Type & Race & Gender & Rank \\
\hline 1 & Burns & Hugh & 08/28/1882 & $8 / 28 / 1882$ & Gunfire & White & Male & Patrol Officer \\
\hline 2 & Ware & Charles & 04/27/1897 & $4 / 28 / 1897$ & Gunfire & White & Male & Patrol Officer \\
\hline 3 & Dolby & Edward & 07/14/1906 & 7/14/1906 & Electrocution & White & Male & Patrol Officer \\
\hline 4 & Russell & Charles & 09/30/1906 & 09/30/1906 & Gunfire & White & Male & Patrol Officer \\
\hline 5 & Petticord & Edward & 09/30/1906 & $10 / 2 / 1906$ & Gunfire & White & Male & Patrol Officer \\
\hline 6 & Irish & Samuel & 07/06/1905 & 6/7/1909 & Heat Stroke & White & Male & Patrol Officer \\
\hline 7 & Krupp & Joseph & 04/19/1910 & 04/19/1910 & Gunfire & White & Male & Patrol Officer \\
\hline 8 & Barrows & Arthur & 06/04/1911 & 06/04/1911 & Electrocution & White & Male & Patrol Officer \\
\hline 9 & McKinney & John & 03/28/1912 & $3 / 31 / 1912$ & Gunfire & White & Male & Patrol Officer \\
\hline 10 & Anderson & Elmer & $1 / 14 / 1915$ & $1 / 15 / 1915$ & Gunfire & White & Male & Patrol Officer \\
\hline 11 & Hagerty & James & 06/23/1916 & 06/23/1916 & Gunfire & White & Male & Lieutenant \\
\hline 12 & DeRossette & John & 01/24/1917 & $1 / 30 / 1917$ & Gunfire & White & Male & Patrol Officer \\
\hline 13 & Ellis & Marion & 01/12/1918 & $1 / 23 / 1918$ & Fall & White & Male & Patrol Officer \\
\hline 14 & Hull & Wade & 09/10/1919 & 09/10/1919 & Gunfire & White & Male & Sergeant \\
\hline 15 & Murphy & Maurice & 03/04/1920 & 03/04/1920 & Gunfire & White & Male & Sergeant \\
\hline 16 & Richards & David & $7 / 2 / 1879$ & 01/03/1922 & Gunfire & White & Male & Detective \\
\hline 17 & Whitfield & William & $6 / 18 / 1922$ & $11 / 27 / 1922$ & Gunfire & Non-white & Male & Patrol Officer \\
\hline 18 & Louden & Jesse & 06/14/1923 & 6/18/1923 & Gunfire & White & Male & Patrol Officer \\
\hline 19 & Buchanan & John & 07/09/1926 & $7 / 6 / 1926$ & Gunfire & Non-white & Male & Patrol Officer \\
\hline 20 & Carter & Charles & 05/07/1927 & $5 / 9 / 1927$ & Gunfire & White & Male & Patrol Officer \\
\hline 21 & Mueller & William & 03/02/1928 & 03/02/1928 & Embolus & White & Male & Patrol Officer \\
\hline 22 & Schoen & Norman & 03/06/1928 & 03/06/1928 & Gunfire & White & Male & Patrol Officer \\
\hline 23 & Miller & Paul & 07/17/1928 & $7 / 18 / 1928$ & Gunfire & White & Male & Patrol Officer \\
\hline 24 & Shipp & Roscoe & 07/23/1929 & $7 / 23 / 1929$ & Motorcycle accident & White & Male & Patrol Officer \\
\hline 25 & Heckman & Carl & 01/03/1931 & $1 / 3 / 1931$ & Gunfire & White & Male & Sergeant \\
\hline 26 & Jones & Lester & 02/07/1933 & 2/7/1933 & Gunfire & White & Male & Sergeant \\
\hline 27 & Quinnette & Orville & $12 / 07 / 1935$ & $12 / 18 / 1935$ & Gunfire & White & Male & Detective \\
\hline 28 & Rivers & Richard & 04/27/1936 & 04/27/1936 & Gunfire & White & Male & Sergeant \\
\hline
\end{tabular}




\begin{tabular}{|c|c|c|c|c|c|c|c|c|}
\hline 29 & Emmelman & Alvie & 05/27/1938 & $5 / 29 / 1938$ & Motorcycle accident & White & Male & Patrol Officer \\
\hline 30 & Bolin & Harry & 08/16/1940 & $08 / 16 / 1940$ & Head Wound & White & Male & Patrol Officer \\
\hline 31 & Reilly & James & 01/29/1942 & $01 / 29 / 1942$ & Motorcycle accident & White & Male & Patrol Officer \\
\hline 32 & Todd & Byron & $10 / 09 / 1942$ & $10 / 09 / 1942$ & Motorcycle accident & White & Male & Patrol Officer \\
\hline 33 & Vaughn & J.W. & 06/06/1944 & 06/06/1944 & War related & White & Male & Patrol Officer \\
\hline 34 & Kornblum & Karl & 08/18/1944 & 08/18/1944 & War related & White & Male & Patrol Officer \\
\hline 35 & Foster & Marshall & 07/04/1947 & $07 / 04 / 1947$ & Struck by car & White & Male & Patrol Officer \\
\hline 36 & Baker & Robert & $10 / 02 / 1948$ & $10 / 2 / 1948$ & Vehicle accident & White & Male & Patrol Officer \\
\hline 37 & Snorden & Clarence & 06/26/1951 & $6 / 26 / 1651$ & Gunfire & Non-white & Male & Patrol Officer \\
\hline 38 & Gaughan & James & 09/08/1951 & $9 / 8 / 1951$ & Car accident & White & Male & Sergeant \\
\hline 39 & Sullivan & John & $07 / 23 / 1952$ & $7 / 23 / 1952$ & Gunfire & White & Male & Patrol Officer \\
\hline 40 & Reifeis & Arthur & $02 / 27 / 1953$ & $3 / 9 / 1953$ & Struck by car & White & Male & Auxiliary \\
\hline 41 & Whobrey & Ray & $04 / 23 / 1953$ & $4 / 23 / 1953$ & Gunfire & White & Male & Sergeant \\
\hline 42 & Berry & Edward & $02 / 02 / 1954$ & $2 / 4 / 1954$ & Motorcycle accident & White & Male & Patrol Officer \\
\hline 43 & Kelly & Albert (Dutch) & $12 / 05 / 1956$ & $12 / 6 / 1956$ & Gunfire & White & Male & Inspector \\
\hline 44 & Byrne & Edward & 04/16/1961 & 4/16/1961 & Gunfire & White & Male & Patrol Officer \\
\hline 45 & Kilbourne & Donald & $11 / 10 / 1964$ & $11 / 12 / 1964$ & Motorcycle accident & White & Male & Patrol Officer \\
\hline 46 & Graham & Thomas & $10 / 12 / 1965$ & $10 / 12 / 1965$ & Gunfire & White & Male & Patrol Officer \\
\hline 47 & Van Wingate & Jimmie & 06/13/1970 & $6 / 14 / 1970$ & Gunfire & White & Male & Lieutenant \\
\hline 48 & Pettitt & John & $11 / 06 / 1970$ & $11 / 06 / 1970$ & War related & White & Male & Patrol Officer \\
\hline 49 & Settles & Floyd & $02 / 24 / 1972$ & $2 / 24 / 1972$ & Gunfire & White & Male & Patrol Officer \\
\hline 50 & Atwell & Robert & $11 / 02 / 1972$ & $11 / 7 / 1972$ & Gunfire & White & Male & Lieutenant \\
\hline 51 & Schachte & Robert & $10 / 22 / 1974$ & $10 / 22 / 1974$ & Gunfire & White & Male & Patrol Officer \\
\hline 52 & Manley & Ronald & $12 / 12 / 1974$ & $12 / 12 / 1974$ & Gunfire & White & Male & Patrol Officer \\
\hline 53 & Greene & Warren & $12 / 20 / 1975$ & $12 / 20 / 1975$ & Gunfire & Non-white & Male & Patrol Officer \\
\hline 54 & Compton & James & 03/16/1976 & 03/16/1976 & Gunfire & Non-white & Male & Detective \\
\hline 55 & Lacy & Ernest & $05 / 22 / 1977$ & $05 / 22 / 1977$ & Vehicle accident & White & Male & Sergeant \\
\hline 56 & Lincks & Nathan & $10 / 25 / 1977$ & $10 / 25 / 1977$ & Vehicle accident & White & Male & Patrol Officer \\
\hline 57 & Griffin & Gerald & 11/06/1979 & $11 / 06 / 1979$ & Gunfire & White & Male & Patrol Officer \\
\hline 58 & Ohrberg & Jack & $12 / 11 / 1980$ & $12 / 11 / 1980$ & Gunfire & White & Male & Detective \\
\hline 59 & Baker & Terry & 01/02/1981 & $01 / 02 / 1981$ & Gunfire & White & Male & Patrol Officer \\
\hline
\end{tabular}




\begin{tabular}{|c|c|c|c|c|c|c|c|c|}
\hline 60 & Morris & Gerald & $01 / 02 / 1981$ & $01 / 02 / 1981$ & Gunfire & White & Male & Patrol Officer \\
\hline 61 & Kortepeter & Paul & $01 / 19 / 1983$ & 01/19/1983 & Vehicle accident & White & Male & Patrol Officer \\
\hline 62 & Sandler & Dave & 06/04/1986 & 06/04/1986 & Vehicle accident & White & Male & Sergeant \\
\hline 63 & Faber & Matt & $08 / 14 / 1988$ & $8 / 23 / 1988$ & Gunfire & White & Male & Patrol Officer \\
\hline 64 & Sharp & Thurman & $12 / 25 / 1988$ & $12 / 25 / 1988$ & Gunfire & White & Male & Lieutenant \\
\hline 65 & Ernst & Paul & $03 / 21 / 1992$ & 03/21/1992 & Motorcycle accident & White & Male & Major \\
\hline 66 & Hawkins & Teresa & 08/17/1993 & 08/17/1993 & Vehicle accident & White & Female & Patrol Officer \\
\hline 67 & Baker & Jason & $09 / 17 / 2001$ & $09 / 17 / 2001$ & Gunfire & White & Male & Patrol Officer \\
\hline 68 & Laird & Timothy (Jake) & $08 / 18 / 2004$ & $08 / 18 / 2004$ & Gunfire & White & Male & Patrol Officer \\
\hline 69 & Moore & David & $01 / 23 / 2011$ & $1 / 26 / 2011$ & Gunfire & White & Male & Patrol Officer \\
\hline 70 & Bradway & Rod & $9 / 20 / 2013$ & $9 / 20 / 2013$ & Gunfire & White & Male & Patrol Officer \\
\hline 71 & Renn & Perry & $07 / 05 / 2014$ & $7 / 5 / 2014$ & Gunfire & White & Male & Patrol Officer \\
\hline
\end{tabular}

